\title{
CONSERVATION OF HISTORIC BUILDING IN THAILAND
}

\section{Pinraj Khanjanusthiti ${ }^{1}$}

\section{Introduction}

The history and the development of conservation practice in Thailand can be divided into three phases: the period before the modernization of the country in the nineteenth century; the transition period; and the period after the establishment of the Department of Fine Arts. The distinctions between the three periods are characterized by the different attitudes towards the historic monuments, and the different conservation philosophy and practice as a result of the social, political, and economic changes. This article will examine those factors that determine the development of the conservation process and its problems.

\section{Conservation before the Nineteenth Century}

\section{Sukothai Period}

There are a number of lapidary and other records of the construction or restoration of monasteries in the past. However, only a few provide enough detailed explanations for us to understand their construction or restoration process. Nevertheless, we are able to conceive the general concepts of construction and the attitudes of the period

\footnotetext{
${ }^{1}$ Lecturer, Department of Architecture

Faculty of Architecture

Chulalongkorn University
}

towards religious architecture. The earlier records of restoration work in Thai history can be dated back to the Sukothai period.

A stone inscription found at Wat Sri Chum, dated around 1345 gives the detailed account of a prince, Mahatera Srisattha, who, following the way of the Buddha, left his worldly life to be ordained in a monastery. His pilgrimage to various places including Sri Lanka is mentioned. During his many pilgrimage trips in Thailand, he performed many meritorious duties which demonstrated not only his support for Buddhism but also his dedication to the preservation of the heritage left behind by ancient forbears. It is mentioned that old stupas and broken stone images were discovered in the jungle by Mahathera and repaired by using lime.

Mahathera returned from the pilgrimage trip to Sri Lanka accompanied by Sinhalese craftsmen. At the time of his arrival, Wat Mahatat, built in the reign of king Rama Khamheng (1275-1317), had fallen into ruin. Mahathera renovated the monastery and enshrined the relic of the Buddha brought by him from Sri Lanka in the main stupa. The inscription mentions the search for fragments of ancient stone images of the Buddha and collecting them together in 
the monastery. The restoration of the sacred images was vividly explained as follows:

“...in one place a neck or a bust had been found; in another place the hair or an arm or a breast; sometime the head had fallen and was far from the body and it needed four men to carry it... All of these stones of the Buddha were of large size. They had to be placed on a barrow or a cart to be transported to the great sanctuary where they were joined together with lime" (Le May 1954: 180).

Meritorious acts similar to the ones carried out by Mahathera have been repeatedly carried out by kings and wealthy Buddhists throughout Thai history. It is a tradition for Buddhists to build, repair, and restore sacred images and religious buildings of earlier date as an act of merit making. The objective of restoration and conservation of the relic of the past, therefore, is considered as an effort to conserve and maintain the religion itself.

\section{Ayutthaya Period}

One of the most important conservation events of the Ayutthaya period was recorded in detail by means of stone inscriptions. The account concerns the meritorious act done by King Taisa (17071732 ) at Wat $\mathrm{Pa}-\mathrm{mok}$. Wat $\mathrm{Pa}-\mathrm{mok}$, situates in the north of Ayutthaya on the bank of Pasak River, was one of the important monasteries of the Ayutthaya period. The important feature within the monastery is a gigantic Buddha image in a vihara. The image is in the reclining position representing the Buddha entering the state of 'parinivarna'. It is built of brick and stucco with a gilt finish and is more than twenty meters long. At the end of March 1726, the vihara was in an imminent danger from the collapse of the river bank. The abbot of the monastery informed the king who promptly took on the mission of safeguarding the Buddha image. Since the image was constructed of brick and stucco and of colossal size, it was suggested that it should be completely dismantled and reconstructed again using the original material as much as possible.

It was a common practice of Thai kings to ask learned monks for advice on various matters especially when the matters were related the religion. Stone inscriptions at the monastery give an account of the Sangha's deliberations which opposed the dismantling of the image. It is mentioned that "After deliberating, they [the Sangha] said: the statue is already the Lord Buddha. It would not be proper to dismantle it in order to remove and reconstruct it." The decision of the Sangha was final and the king ordered the image to be removed intact. The inscriptions also give a detailed account of the operation which involved elaborate engineering works and a great expense of time and man-power. It must have been an ambitious project when we consider the viability of the machinery for the task. The vihara was demolished and the image was moved 168 meter further from the river bank where a new vihara was built over.

The inscriptions are a rare example of their kind, since they do not only give details of the operation that illustrate the technology used but also indicate the attitudes of the period towards the sacred image and the monastic building. We can conclude that the image was valued as the most important structure and was the priority in the entire operation, while the destruction of the building was not taken to be of any importance. It is not the architectural fabric but the spiritual representation of the Buddha that was the aim of the activities to safeguard it. 


\section{Bangkok Period}

During the three hundred years of the Ayutthaya kingdom Thailand was involved in several major wars with Burma which resulted in many victories as well as defeats on both sides. At the end of the eighteenth century, Ayutthaya engaged in the final war which resulted in the fall of the kingdom in 1767 . The capital suffered greatly as the consequence of the war. Most of the architecture, art, and literature were destroyed overnight. Most of the population migrated to safer places and Ayutthaya was deserted. Tak-sin, a Thai general, led a small army to fight against the Burmese and restored the independence of the country. Having seen that Ayutthaya was in a dilapidated state, impossible to be reconstructed without exhausted manpower, he moved the capital to Thonburi, an old custom post on the west bank of the Chao Praya River. Thonburi period is one of the most critical period in Thai history. It was the time of the restoration and preservation of national independence. The new capital was not properly built. Social and economic improvement as well as political stability were the priorities. The political situation, however, was in turmoil until the end of King Tak-sin's reign.

In 1782, a new king ascended the throne. Rama I, the first king of present Chakri Dynasty, served as a high ranking officer in the Thai army and fought against the Burmese along side King Tak-sin. The new king decided that geographically Thonburi was difficult to defend if it were to be invaded again by the Burmese. It was also constricted by canals to permit future expansion. So, he moved the capital to the small village of Bangkok, on the opposite bank of the river.
Apart from the restoration of the political, social, and economic systems, the king also took on the duty of a Buddhist king to restore the stability of the religion. Buddhist scriptures, destroyed during the Ayutthaya war, were gathered and Pali texts were translated. Rama I had the ambition to build a new capital which would have match the glory of Ayutthaya. Therefore, the creation of art and architecture in the Early Bangkok period, especially during the first three reigns, is characterized by looking back to the past in the attempt to recreate a lost heritage. After the fall of Ayutthaya, the new capital was established in Bangkok and vigorous construction programmes were carried out. These included the building of several major monasteries and large Buddha images. A number of Buddha images were also transported from Ayutthaya and other towns in order to be reestablished in royal monasteries in the new capital.

Wat Po is one of the monasteries restored by King Rama I. The work started in 1789 and lasted for twelve years. A stone inscription on a wall of a vihara gives an account of the construction of a new ubosot, surrounding cloisters, several stupas, and other buildings. It also mentions the transference of more than two thousand Buddha images from Ayutthaya, Pitsanulok, Lopburi, and Sukothai to Bangkok. Most of the images were damaged. The king gave orders to have them restored by adding the missing parts, and "beautifying" the faces. The images that were made from brick and stucco were repaired and regilded. After the restorations were complete, the important images were installed in different viharas of the monastery while the lesser ones were placed along the cloisters. Here one can see the similarity of the restoration works 
carried out by Rama I and the works of Mahathera Srisattha of Sukothai four hundred and fifty years previously.

The restoration of monasteries by the successive kings was intensively pursued. The nature of the intervention always involved the demolition of old structures and their replacement with new architecture in the style of the period. One of the examples which illustrates the typical restoration method of a stupa is at a monastery at Nakorn Pathom. The town lies about thirty miles to the west of Bangkok. According to local tradition, the city, situated on the site of an ancient city called Chaisiri, is believed to have been visited by King Asoka's Buddhist missionary. Even though this claim is rejected by some modern historians, the area around Nakorn Pathom is surrounded by remains of ancient stupa. Resent excavations reveal ancient images and other art objects that display the strong influence of the Gupta tradition. There is also a speculation that Nakorn Pathom may have been a sea port and the capital of the Dvaravati Kingdom.

Before his accession, King Rama IV who at the time was in monkhood, made a pilgrimage to the city. There he found the ruined dome of an ancient stupa. According to archaeological evidence, the stupa was constructed by the Mon in the style of a Singhalese dagoba (stupa) and can be dated back to the first Dvaravati settlement. ${ }^{2}$ The stupa had undergone some restoration even before the king's discovery. It appeared that a Khmer style sikhara had

\footnotetext{
${ }^{2}$ The exact date of this ancient stupa is still debatable. It ranges from the first to the eleventh centuries.
}

been constructed on the top of the dome to replace the missing original spire. The date of the new structure is given between 1000 $1400 \mathrm{AD}$. The ruin of this tower was still standing in the nineteenth century though completely overgrown with vegetation. The restoration of the old stupa did not start until King Rama IV ascended the throne. The work began in 1853 and lasted for seventeen years. The king died before its completion and the work was carried on by his son, King Chulalongkorn.

The restoration of the stupa by Rama IV typifies the ancient way of restoring stupas in Thailand. An old stupa was usually enclosed within a new larger and taller structure which could be of different style. At Nakorn Pathom, the new structure does not bear much resemblance to the original and is very much larger. It became the tallest and the largest stupa in the country. 120.45 meters in height, 233.5 meters in circumference and covered with orange glazed tiles, it dominates the plains for miles around. The king also built a round gallery surrounding the stupa and four viharas at the four cardinal points. It is interesting that the restoration work was recorded, though not with architectural or archaeological correctness. A replica of the old stupa was built on the outer platform to the east of the gallery. It was from this model that archaeologists and historians have speculated on the style and the date of the original structure.

This intervention on the monument, again, emphasises the restoring of the structure to its original glory, or what the original should have been, regardless of the archaeological or historical evidence. The stupa became once again a shrine suitable in every way for the relic of the Lord Buddha and resumed its function as the 
centre of pilgrimage as it was in ancient times. This intention is illustrated, though indirectly, by the mural painting in the main vihara. It depicts the original stupa enclosed within the new structure. The walls of the chamber also contain murals showing gods, angels, and various mythological creatures paying homage to the great stupa.

\section{The Roles of Kings in Caring for Monasteries}

In the past, most of the restoration works was carried out under the kings' orders. The role of the Thai king as a supporter and protector of Buddhism and the Sangha had existed since the beginning of the Thai Kingdom. Kingship and religion were interdependent since the stability of the country and the well being of the nation depended upon both institutions.

Throughout the Sukothai and Ayutthaya periods, the relationship between the state and the Sangha was closely knit. Buddhism, in a way, was exploited by politics. It was used to legitimize the king as claim to the throne especially when that king was an usurper. Buddhism was manifested in the unification of Ayutthaya and Sukothai in the reign of King Trilok of Ayutthaya (1448-1488). Although Sukothai was under Ayutthaya's rule, it was still not totally subdued. It has been suggested that the king succeeded in integrating the two kingdoms because he understood the importance of Buddhism and recognized that military occupation alone would not be able to ensure stability. The king temporarily left the throne to be ordained and stayed for a period in a monastery in the north. He also made great efforts to restore and build monasteries in that region.
Among these activities, which gave him the reputation of being a good Buddhist king and which greatly impressed the population of Sukothai, was the restoration of Wat Mahatat (Temple of the Great Relic) in Pitsanulok which once was the centre of the Kingdom.

It was an ancient tradition that when a new king ascended the throne, he would build a new monastery or completely restore an existing one. That monastery was regarded as the royal monastery of that reign. The vast number of monasteries and the magnificence of the buildings signified not only the stability of the reign and prosperity of the religion but also the righteousness and merit of the ruling king. The king's meritorious acts would be followed by members of the royal family, nobles and wealthy patrons. This resulted in the large number of monasteries in the country both under the royal patronage and privately built and the vast amount of land donated to monasteries. Today the building of a new monastery is no longer practised. Most of the money donated to a monastery goes to the repair or restoration of the existing fabric or the construction of new buildings for the benefit of the community and the monastery such as schools, multi-purpose halls, and new ubosots or viharas.

\section{Slave Endowment}

Another tradition that was practised by the kings of the Ayutthaya and Early Bangkok periods was the donation of slaves for working in royal monasteries. During the Ayutthaya period when there was a shortage of man-power because of the wars with Burma, large numbers of the population were recruited by the government to do military service and work as forced labour. This drove many people into hiding. It was suggested that one 
method of avoiding becoming an outlaw was to register with the government as a monastic slave or Kha Phra (Suksamran 1992:14). Kha Phra were also slaves captured from countries defeated in war (Pramoj 1982:18-19). The aim of SouthEast Asian warfare in the past was not only to extend the country's boundaries but also to find new human resources. It was then a common practice of the victors to take away the people of a defeated country as slaves, as well as to loot their cities. Most of the captives belonged to the king and were categorized as royal slaves. They would be distributed by the king to high ranking commanders as a reward and were also donated to royal monasteries. Kha Phra were required to look after the monastery and provide security for its sanctuaries and properties. If the monastery also possessed agricultural land, they also had to work on the land for the benefit of the monastery.

Slavery in Thailand was abolished in 1874 by King Rama V. The abolition was a nonviolent but long and gradual process. It took more than thirty years totally to eradicate the system of slavery from the country and it brought about changes within the social and political structure.

The care of monasteries, especially the royal ones, was affected by these changes since most of the care of the monastery fabric had been done by the Kha Phra. Two years after the last legislation for the abolition of slavery was enacted, a new policy for the care of monastery fabric was established to solve the problem which resulted from the loss of essential manpower.

The policy divided the royal monasteries into four categories in order to define the amount of money and man-power each monastery should receive as a subsidy from the government. The monasteries in the first group were classified as of special importance. They were monasteries built by the king of each reign and regarded as the royal monastery of that particular king. Wat $\mathrm{Po}$ and Wat Bavornives in Bangkok were examples of this category. Monasteries containing chetiya or stupas with relics of the Buddha were included such as the monasteries of the Great Relic outside Bangkok, and Wat Phrabat where the foot prints of the Buddha had been found. These monasteries received money and man-power for maintaining their fabric. The sum of money was not fixed, but was dependent on the requirement of each monastery.

The second category was all the other monasteries built by kings within the capital city. These monasteries received a fixed amount of money once a year. It was mentioned in the official announcement that the money was for repairing the fabric in time for the Katina ceremony which takes place at the end of the rainy season retreat. In addition to this, the monasteries received a separate sum of money to pay for the monthly salaries of three men to do the maintenance work.

Monasteries in the third category were those built by kings in other towns outside Bangkok and those built by members of the royal family by royal command both within and outside the capital. The final category consisted of monasteries built by members of the royal family or by high ranking government officials who presented them under royal patronage. The last two categories received the same kind of subsidy as the second category. However, the amount of money and hired labour was 
reduced according to the category. The granting of government subsidy was the responsibility of the Department of Church Administration (Krom Dharmakarn), a ministerial department whose duties included the inspection of monastic revenue and the management of monastic lands.

We do not have much information on how small privately built and village monasteries were looked after or about their financial situation at this period. But it can be assumed that the abolition of slavery may not have had much effect on these monasteries since they probably did not have access to slaves in the first place. It was always the duty of monks in the monasteries and their communities to care for and maintain the fabric by using money from donations.

\section{The Roles of Sangha}

The Sangha have always had the duty to care for their dwellings and monasteries. Even though there is no direct rule relating to the care of a monastic fabric mentioned in the Vinaya, it is generally agreed that cleanliness and tidiness are the qualities required of dwelling places. The abbot of a monastery also has a duty to report on the condition of the monastic fabric to the appropriate authorities in order that repairs can be carried out. Before the establishment of the responsible organization, the condition of a monastery and its environment depended solely on its abbot and the Sangha community. The Sangha have also an indirect role in caring for monasteries. In the past, they acted as advisors to the kings and lay-community. Learned monks were consulted by kings not only on religious matters but also political and social problems. The monks who supervised the kings were usually the Supreme Patriarchs who were chosen from monks associated with religious dwellings under the king's support, or from the monks who were of royal descent (Suksamran 1977: 31). In some particular matters, a committee of learned monks was appointed and consulted.

The advice of the Sangha was, inevitably, based on Buddhist philosophy and ethics. Therefore, advice on the care of the monastery and sacred structures was very much influenced by religious attitudes towards the subject. The judgement of the Sangha was considered to be final as illustrated by many examples in the past.

\section{Merit Making and the Care of Sacred Buildings}

In Thailand, the construction and the care of monasteries are very much related to the concept of merit making. In order to understand the philosophy behind the conservation and care of religious buildings, it is necessary to understand the religious philosophy and beliefs that together form the architecture and its context.

Buddhism in Thailand has a complex background. It is an amalgamation of several beliefs which form the characteristic of Theravada Buddhism of South-East Asia. Three different "norms of conduct" can be distinguished (Spiro 1972). Even though the aim of religious practice is to discover the way of release from the endless cycle of existence, or to reach Nibbana, this concept is confined to a small group of people whose primary concern is with salvation. Another group is the majority of the Buddhist population who 
consider the cycle of rebirth as a kind of religious pilgrimage and the doctrines comprising this system provide the means for enhancing one's position within the cycle by improving one's karma. Apart from these two types of canonical Buddhism, there is also a non-canonical type which is concerned with man's worldly welfare. In this type, religion is used as a protection from devils, to care for the sick and as an aspect of mythical belief.

In Thailand, the knowledge of sophisticated doctrines is restricted to dedicated monks and a few lay-people. Most Thai, though understanding that Nibbana is the ultimate aspiration of life, believe that Nibbana cannot be achieved in a single lifetime and do not consider Nibbana to be a religious objective. The religious aspiration of ordinary Buddhists is the hope to be reborn in a better world. Better status in a future life or a time in paradise are the less abstract versions of the ultimate goal. Since Nibbana cannot be achieved in a single life time, it needs the accumulation of good deeds done by an individual throughout his previous existences which will, in turn, result in the spiritual perfection.

Though Buddhism regards life as suffering, to be born as a human being is considered a good position. This is because human beings have the opportunity to be exposed to the faith and to gain merit for attaining enlightenment in a future life. Most Thai are linked to Buddhism through popular beliefs about merit (punna) and demerit (pub). The relationship between merit and karma is explained as follows:

"It is merit that determines one's destination; that is why some people are born with wealth, wisdom, beauty, power, and have long lives as against the ones who are born with poverty, suffering, ugliness, idiocy, and have short lives. Merit and demerit determine who will be the ruler and who will be the servant or governed..." (Tambiah 1975).

Merit is gained by several means, for example, by giving gifts, particularly to monks, by leading a pure life and by observing the Five Precepts in order to avoid demerit. Merit is also gained from worship. This means the worship of "the visible traces of the Buddha on earth." Stupas and shrines are the focus of this worship. The worship or "puja", requires the offering of food, flowers and sometimes money and also the performance of particular rituals, such as the circumambulation of a stupa. It is generally believed that the most meritorious action a layman can perform is to give money to the Sangha for the construction of a monastery. This concept has been long established. An example is illustrated in the story of Visaka, a wealthy lay-follower living in the time of the Buddha, who funded the construction of a dwelling for monks and gave many gifts in accordance with a wish that she had made in her former life. The story was recounted by the Buddha to his disciples and, at the end, the notion of acts of merit was explained:

"As from a heap of flowers one can make many a garland, even so many good deeds should be done by one born a mortal" (The Dhammapada trans. by Narada Thera 1959: 27).

However, monastery building involves a great deal of labour and financial resources. It is clear that very few individuals have adequate means for such donations. Most people contribute smaller sums, sometimes as part of a Katina ceremony, which may be used for building, repairing or restoring a monastery fabric. 


\section{Conservation Practice as Mentioned in the Mahavagga}

The problem of dealing with the repair or restoration of sacred structures and images must have existed since ancient times. The Chulakanti Pakorn, which is an amendment chapter of the Mahavagga, mentions the restoration of ruined stupas and Buddha images as follows:

"In the case of the stupa that falls into a ruinous state, without anyone to look after it, is situated in an unsuitable place, or situated among sinful people, if any merit-seeking individual intervenes with it in any respect or dismantles and restores it into its normal condition, he will receive as great merit as in the case of the royal doctor, JivakaKomarabacca, who bled the bad blood from the Lord Buddha."

The explanation from the text is not clear especially when one considers what is permitted to be done on the fabric of a monument. But what is obvious is that restoration and acts of merit are strongly related and that architectural fabric is not considered as important as its symbolic representation. This concept is understandable, since the Chulakanti was written when religious ideology was the only consideration when dealing with sacred monuments and images. Even in the early years of this century, when the archaeological value of a monument had been realized, the Chulakanti was still used as a point of reference by the Sangha

\footnotetext{
${ }^{3}$ Author's translation from 'Phra Maha Sammana Vinitchai' which is a compilation of reports from the Council of Elders in 1914, headed by the Supreme Patriarch, Prince Vajirayanavaroros.
}

Council for judging applications for the restoration of monasteries throughout the country.

In 1914 the Council of the Elders (Mahathera Samakom) considered an application for repairing an ubosot which involved the demolition of a group of sacred images. Prince Vajirayanavaroros, the Supreme Patriarch at that time, referred to the text of the Chulakanti Pakorn and reinterpreted it to signify the concept, for example:

"Anyone who, with bad intention, damages or destroys stupas or Buddha images, their wilful actions are interpreted as sinful. Examples of bad intentions were given such as digging for buried treasure, relics or amulets; demolition of sacred architecture in order to gain an empty piece of land for building their own dwellings or farming; or destroying monuments because of different belief, hatred or jealousy. On the contrary, actions done by people with good intentions are acceptable and considered to be acts of merit. Example of these include: the demolition of a ruined stupa and the rebuilding of a new one in the same place; the alteration of a ruined stupa in order to improve the structure; the demolition or dismantling of a stupa not of great beauty and rebuilding one which is more beautiful; the removal of a stupa that had been situated in an unsuitable place to a new place deemed more suitable." 4 The unsuitable places were referred to by the supreme patriarch as places where there would be no Buddhist to look after the structure. In the case that the whole structure of a stupa could not be removed,

\footnotetext{
${ }^{4}$ Author's translation from 'Phra Maha

Sammana Vinitchai', as above.
} 
dismantling of the old structure and using the old materials to build a new one was acceptable, even though the new structure was not the same in appearance as the original. These principles were applied to Buddha images as well.

It can be concluded from the opinions of the supreme patriarch and the Sangha Council that the 'objective' of any intervention was considered the most important factor. No matter what degree of intervention was involved, if it was done with a pure and moral mind (kusala), the deed was considered acceptable.

\section{The Development of Early Legislation}

The law relating to the care of religious monuments in Thailand did not exist until 1854. However, an awareness of the importance of sacred structures and images had long been recognized. The care of monuments in Thailand before the nineteenth century was largely dependent on the personal initiative of individual rulers. It stressed the protection of the religious institution rather than the cultural significance of the structure. This can be seen by studying the ancient law promulgated at the beginning of the Ayutthaya Kingdom (1350). The law included traditional Thai customs and was subsequently modified by assimilation with the Laws of Manu, the ancient Indian law and social ideology dating from the second to first centuries BC. The law provided the basic principles of Thai law until the reign of King Rama V (1868-1910) when it was replaced by modern legislation.

One section of the ancient law dealt with corporal punishment for crimes that related to religious monuments and images. Here the various acts of offence and vandalism are mentioned: for example stealing Buddha images from a monastery; smelting gold from images or stupas; vandalizing stupas, viharas, images or sacred Bodhi trees. Those who committed these criminal acts were regarded as sinners who must be persecuted. The corporal punishment mentioned in the law was rather severe ranging from lashing to various kinds of torture with execution as the final penalty. The methods of punishment seem incongruous with the Buddhist concept of compassion and non-violence. However, the justification for the law was given as the need for protecting the sacred representations of the religion itself.

The growing interest in safeguarding the national heritage as artistic and historical evidence started in the reign of King Rama IV. The idea was stated in a royal edict, issued in 1854, concerning the care of monasteries in the country. The problem of looting and treasure-hunting in monasteries was still continuing at this period no matter how harsh the corporal punishment was. Therefore, the purpose of the edict was to prevent the further damage to a monastery by keeping it under surveillance. If any damage caused by looters was found on the structure of ubosot, vihara, stupa, or Buddha images, the people who lived in the vicinity of the monastery were obliged to report this damage to the authorities within one month. If they neglected to do so, they were obliged to restore the structure to its former state at their own expense. The purpose of this decree was stated at the end of the edict as follows:

"The purpose of this [decree] is to encourage the people to look after the monastery that is close to their residences, not to let any one dig up, 
damage, or destroy the sacred place. Since the monasteries were built by our ancestors, using bricks, mortar, stones or other materials, large or small, even though in decay, they are still the elements which adorn our city."

\section{The Transition Period}

The influx of western influences during the reign of King Rama V not only transformed the characteristic of Thai art and architecture but also the attitude towards them. The interest in art and archaeology was started among the new generation of educated Thai. It was the first time that the national heritage was regarded as an object of art distinct from its religious context. However, the enthusiasm towards conservation was confined the area of antiquity. Archaeological research was started by individual initiative focusing on the ancient artifacts. This group of people consisted of members of the royal family, western educated Thai, and foreigners living in the country. Several excavations were carried out on various sites. These resulted in a better understanding of the history and the development of art and architecture. Art objects were collected from sites all over the country and the National Museum was established.

\section{The Western Approach to Conservation in Thailand}

The systematic study of the archaeology and history of monuments in Thailand and elsewhere in South-East Asia began in the late nineteenth century. It is suggested that colonial conquest was the origin of the study of Indochina (Groslier 1970:155). Even though there had been relationships between the kingdoms in the area and the western world since the sixteenth century, the interest in art and archaeology was previously not developed. The European quest for knowledge in the field of human science during the nineteenth century was one contribution to the study. The Royal Geographic Society in London was one of many organizations who sponsored several explorers to distant lands. In 1858 , Henri Mouhot, a French naturalist, made a journey to Thailand and, later Laos and Cambodia with encouragement from the Society. It was during this expedition that he visited the ruined city of Angkor. The study of Indochina attracted a lot of attention from the west and several permanent research institutions were established as a result. The Ecole Francaise d' Extreme Orient was founded by the French to carry out research and survey monuments and archaeological sites in French Indochina as well as studies of the history and languages through ancient inscriptions.

The Ecole Francaise d' Extreme Orient played an important role in bringing Indochinese archaeology to light. The first inventory of Khmer monuments in Cambodia and Thailand was drawn up by Lunet de Lajonquiere in 1900 . This inventory was used by the Thai authorities as one of the fundamental pieces of information for surveying monuments in the country. In 1907, the French successfully forced Thailand to surrender the provinces of Siemreap and Battambong in which Angkor and other principal Khmer monuments are situated. The Angkor Conservancy, an office responsible for the documentation and conservation of the monuments, was set up and conservation works were carried out. The method and philosophy used in the conservation of Angkor later became one of the popular 
approaches used in Thailand at a later date.

Even though Cambodia, as in Thailand and Laos, possessed Buddhist monuments which were very much in use, the works of the French in Indochina dealt entirely with ruined stone monuments. It is possible that the interest of the western nations in SouthEast Asian culture was triggered by a romantic approach to an ancient and unknown civilization. It is mentioned that "The basis of our concern with archaeology or, more generally, with Oriental studies is, quite simply, a curiosity about man" (Groslier 1971: 250). The zeal of the West in the study and conservation of historical heritage derived from the attitude towards colonialism that prevailed during the period. It was generally believed by the western countries that it was the duty of a civilized nation to safeguard world heritage from the negligence and ignorance of the native people. The idea was expressed in many writing by the leading figures both French and British. Sir Stamford Raffles wrote with naive enthusiasm as follows:

"[We must collect] the scattered remains of the literature of these countries...The rays of intellectual now divided and lost will be concentrated into a focus from which they will be radiated with an added lustre, brightened and strengthened by our superior lights...If the time shall come when [Britain's] Empire shall have passed away, these monuments of her virtue will endure, when her triumphs shall have become an empty name... Let [Britain] be remembered...as the gale of spring, reviving the slumbering seeds of mind, and calling them to life from the winter of ignorance" (Raffles cited in Groslier 1970: 254).
The ruined temples of Thailand and Cambodia were restored by the method of anastylosis. It is noticeable that the monuments that caught the attention of the West were constructed of stone. From a practical point of view, stone and its construction technique were more familiar to the West than other kinds of materials used by indigenous peoples. As the result, the stone monuments of Thailand and French Indochina were intensively studied, recorded, and restored while other kinds of monuments were not given so much importance. Monasteries which can be considered as centres of traditional art and crafts were, at the beginning, disregarded by western scholars as unworthy of study. James Fergusson (1808-1886), an architectural historian who was the first in England to set about writing a world history of architecture, writes about monasteries in Burma as follows:

"The travellers who have visited the country have been silent on the subject, principally because the monasteries are, in almost all instances, less magnificent than the pagodas to which they are attached, and are, with scarcely an exception, built of wood - a practice destructive of their architectural character, and also depriving them wholly of that monumental appearance of stability which is so essential to true architectural expression" (Fergusson 1899: 626).

The early study of South-East Asian architecture shows the subjective interpretation of historians towards incomprehensible art and culture. Fergusson, again, gives his opinions about the lavishly decorated monasteries in Burma and Thailand as the representing "...a building such as the West never saw, and, let us hope, never will see; for, 
however dazzling its splendour, such barbaric magnificence is worthy only of a half-civilized race" (Fergusson 1899: 628). It was more comprehensible for the West to study architecture as an object of art and research into its origin. Together with the idea of conserving the neglected remains of a past civilization, the ruined monuments and archaeological sites were the focus of attention rather than the living monasteries. Western archaeologists were able to impose their own methods of research and conservation approaches on the ruined monuments without creating much conflict with local people who still carried on the traditional way of caring for their living monasteries. There were however some restoration works that related to monasteries and their occupants; in these cases the western conservation approach had to give way to the traditional method of repair. The restoration of temples in Pagan in Burma was carried out by the Burmese Archaeological Survey. They were "...anticipated by the monks, whose zeal - comprehensive but somewhat overpossessive - led them to undertake lavish white washing or regilding operations, or in some cases to adopt the alternative solution of applying a fresh layer of brick or stucco" (Groslier 1971: 180).

\section{The Nature of Repair}

The distinctive character of Buddhist monastic architecture in Thailand is lavish decoration of architectural elements. Gold leaf, mirror tiles and ceramic tiles are common materials used for exterior decoration. The materials are used as part of the intricately carved timber or stucco motifs. Tiles are cut into small pieces and arranged into delicate low-relief patterns. It is inevitable that these detail decorations, which have a relatively shorter life-span, rapidly deteriorate in the intense heat and the heavy rain fall of a tropical climate. The nature of the deterioration of architectural surfaces involves the fading of the gold leaf, dull coloured glass, and the loosening or breaking of tiles on the relief patterns. Hard tropical timber is the main construction material for the roof structure, windows, and doors, and other decorative elements such as ceiling and eave brackets. This timber suffers from the effects of weather as well as from fungus and insects. It would have been more efficient if problems could have been detected earlier so preventive measures could be carried out. However, most of the Thai monasteries did not have a regular inspection programme. It always was too late when the problems of deterioration became evident.

During the early part of this century, there were several major restoration works carried out in various monasteries under the patronage of King Rama V. The records of all the restoration works, which were always major interventions, illustrates the norm of practice. The restoration often involved replacement of materials of both decorative and structural elements that had deteriorated far beyond the point of repair.

In 1839 , sixty-three years after the major restoration by King Rama III, Wat Po in Bangkok was in the state of disrepair. A detailed proposal for its restoration was drawn up by the order of King Rama V. A proposal written by Prince Narisaranuvatiwong, the royal architect, mentions that most of the architecture in the monastery was in a dilapidated condition. In his report, Prince Naris suggested the demolition of several structures which were 
too decayed to be repaired. ${ }^{5}$ A number of structures pending demolition were stupas within the Buddhavas area. The stupas are components of the whole lay-out of the Buddhavas complex. The ubosot which is the centre of the complex is surrounded by double cloisters with a small vihara at each of the four cardinal points. Seventy-one small stupas are placed at close intervals outside and follow the outline of the cloisters. At each corner of the cloister, a group of stupas is constructed. Each group consists of five stupas on the same pedestal, with the central stupa slightly larger than the others.

The restoration proposal mentions that all of the four grouped stupas were to be demolished and out of the seventy-one small stupas, only thirty-two would be repaired while the rest would be demolished. The restoration programme was divided into several phases and would last for seventeen years. It was carried out until the end of the reign, when King Rama VI took on the task. However, the restoration records of the later period do not mention the demolition of the stupas. The plan must have been altered at a later date.

Nevertheless, other proposed schemes were carried out. The vihara that enshrined a reclining Buddha image, built in the reign of King Rama III, was in disrepair when the restoration programme took place. The roof of the building was repaired and the timber roof decorations were removed. The

\footnotetext{
${ }^{5}$ Information on the restoration of Wat Phra Chetupon (Wat Po, Bangkok) was taken from documents of The Ministry of Engineering service in the National Archive, Bangkok, dated between 1837-1839 as well as records of restoration works published by Wat Phra Chetupon (see bibliography).
}

elements that were decayed beyond repair were replaced with new ones using the same design and material. The surfaces of the timber elements that were finished with gilding or mirror tiles were stripped off in order to be regilded or replaced with a new layer of tiles and gold leaf. Both exterior and interior walls were re-plastered and mural paintings inside the vihara repainted. The windows and doors, decorated with gold gilded patterns on lacquer surfaces, were in a dilapidated condition. It was planned that all of windows and doors were to be repainted and regilded.

The proposal of the restoration signifies the two different approaches to the care of a living monument. The traditional methods of repair were undertaken without concern for the archaeological value of the structure. It is mentioned in the proposal that the objective of repairs was not to make the old look new as if they had been just constructed but to repair the dilapidated elements so that they retained their use and durability. It also illustrates the attitude of an architect of the period towards monastic buildings. Prince Naris proposed the demolition of the stupas even though, as seen from an architectural point of view, they are part of the architectural elements that form the unified plan of the Buddhavas area. The proposal was made about sixty years after the vihara and the seventyone small stupas had been constructed. Therefore, it is possible that the structures were seen not as historical architecture but functional and contemporary ones.

During the reign of King Rama V, there was no legislation directly related to the care and conservation of historic monuments. Nevertheless, an interest in antiquity arose and was promoted by the king. The Archaeological Society 
(Borankadee Samosorn) was established in 1907 under royal patronage. The role of the Society was to raise public awareness of the importance of national monuments and antiquities. During this period, the king issued an edict protecting the ancient city of Ayutthaya as a national heritage site. In the reign of Rama VI, the care of national heritage became an activity of the royal government. In 1923, the king established a committee responsible for this task. Codes of practice were issued. The content of the codes dealt mainly with the survey and selection of ancient artifacts and monuments by the committee, and the roles of the committee as an advisory body for local authorities in matters dealing with national heritage. Even though the king passed away two years after the committee was established and the committee was annexed to a new institute founded by the succeeding king; it was the first step to an organized body directly responsible for national heritage.

\section{The Royal Academic Council}

The Royal Academic Council was established by King Rama VII in 1926. It was divided into three divisions, namely: Art and Craft, Literature, and Archaeology. The works of the Archaeology Division ranged from caring for archaeological sites and artifacts in the country to museum management. The conservation policies and the practical approach of the Council were established by using western examples carried out by western archaeologists as they had always done in other countries in South-East Asia. National heritage was categorized into two groups. The first group consisted of monuments and sites such as cities, important buildings both secular and religious, and ancient man-made structures such as reservoirs and bridges. The second group concerned movable objects, for example stone inscriptions, Buddha images, and other artifacts. Criteria for determining the values of monuments and artifacts were established by the Council. Two factors which were considered important were their historical and artistic value. How these values could be established was explained by Prince Damrong Rajanuparb, the first president of the Council, in his lecture given in November 1930 which can be regarded as a landmark document in conservation in Thailand.

Monuments, sites and artifacts that could be related to a particular period or important events in Thai history were of historical value. The monuments or artifacts that showed distinguished craftsmanship or were the specimen of a particular style from the past were considered as having artistic value. This lecture is the only written document describing the conservation approach of the council. At that time, however, there was no legislation issued by the government to support the Council in carrying out its conservation works. The pioneers in the conservation field undertook their projects within many constraints and experienced many difficulties. The early work of the Council was to make an inventory of important monuments and artifacts in the country. Since the Council was centralized, this being unavoidable because of the limited number of staff, it asked for collaboration from local authorities to inform it of monuments and artifacts in their region. The inspectors were sent by the Council to inspect the condition of the monument and an inventory was made. One of the purposes of the inventory was to use it as a reference for judging which monuments should be 
given priority in conservation. Since there was not a large amount of government funding, the monuments had to be classified and work undertaken according to their condition and need.

Three degrees of intervention were set up, beginning with a programme to recognize the monuments. Though this process is similar to the listing of historic monuments, there was no legislation to support this process. The next step was to put a kind of structural support around the monument to prevent further deterioration. The work of this kind was carried out on both stone and brick buildings. Scaffolding for supporting the structure was built using timber, bricks, and, at a later date, reinforced concrete. The third degree of intervention was total restoration. It was mentioned in the lecture by the president of the Council that this method was tried at a stone Khmer temple in Lopburi and it was also being put into practice by L' Ecole Francaise d' Extreme Orient at Angkor Thom in French IndoChina. The method used here was anastylosis which was an acceptable conservation technique for restoration of dry stone masonry. Though the ethic in restoration has always been arguable and the technique has never been satisfactory when used on brick and stucco buildings. The Council did not mention the method of intervention between the supporting of a structure and the total restoration nor did they object to anastylosis. But the Council realized there was a loss of historical value when restoration was undertaken. Prince Damrong Rajanuparb illustrated examples of several monastic buildings that were repaired or reconstructed not in keeping with their original style. The Council also asked a local authority to supervise the repair or restoration of any historic building in their area, so that there would be no change in the style and details of the original. In the case of monasteries, a local authority had a duty to explain these principles of conservation to the monks. If there were any problems related to the restoration, the Council should be immediately informed in order that expert advice could be given or the Council could intervene in the restoration process when necessary to prevent damage to the monument.

An important task of the Council was to raise awareness of the value of cultural heritage among ordinary citizens. During this period, antique collection had become a fashion among the elite Thai as well as among foreign visitors and there were several reports to the Council about the looting of monuments by treasure hunters. Deserted monuments in remote parts of the country suffered the most.

The establishment of the Royal Academic Council was the first step to a more organized conservation practice based on western models. The Council was started from devotion of like-minded people who realized the necessity of systematic conservation. However, they had to overcome many obstacles such as the lack of qualified personnel and funding. This is mentioned in a letter from Professor George Coedes, a French archaeologist and advisor to the Council, written to Prince Damrong in 1929 that:

"I have a sad feeling that... when I shall retire, nobody in Siam will be able to read a Sanskrit, Cambodian, or even old Thai inscriptions...The collaboration with Your Royal Highness in the creation of the Archaeological Service and of the Museum has been for me a source of immense satisfaction, but here again, 
owing to lack of funds and of staff I cannot see the realisation of what $I$ deem most essential in that connection: I mean a full and detailed survey of the antiquities of Siam, and a numbering and cataloguing of the objects kept in the Museum" (Coedes's letter: National Archive).

Until 1926, there was no legislation enacted by the government directly concerned with the conservation of historic monuments. The first legislation related to the caring of national heritage was aimed at protecting artifacts which, at that time, were being widely excavated and smuggled out of the country. Important monuments were recognized and protected to a certain extent. However, the care of most of monasteries still very much depended upon their patrons and monks while the quality of the repaired work depended on employed local craftsmen.

\section{Conservation after 1932}

1932 saw Thailand enter another major period of change. On June 24, 1932 a revolution broke out, bringing in a new era of constitutional government and ending the seven hundred year rule of the absolute monarchy. The political change had an indirect impact on the care of national heritage. The duty that had always been under the patronage of the kings and royal family was transferred to the government. In 1933, the work of the Royal Academic Council in matters relating to national museums and the care of the historic monuments was transferred to a newly established body: the Department of Fine Arts. In 1934, the first legislation for the care of historic monuments and ancient artifacts was issued and historic monuments were listed for the first time. From then on there have been several amendments to the legislation and several restoration programmes have been carried out.

During this period, there were collaborative projects between Thai and French archaeologists in many parts of the country. The Ecole Francise d' Extreme Orient made an agreement with the Thai authorities on the excavation of archaeological sites in 1937. According to the agreement the Ecole would send a French expert to Thailand to supervise the excavation and research. The Thai authorities had priority in selecting the finds from the sites for the national collection while the French received according to the proportion of the money that they spent in the operation. The first site that was excavated by the Ecole was at Wat Pra-meru in Nakorn Pathom.

\section{French Restoration Works in Thailand}

Restoration of historic monuments by the French and the Department of Fine Arts was carried out on stones temples in the north-east of the country. The restoration method that the French commonly used was anastylosis. It was also successfully used by the Netherlands Indies Archaeological Service in restoring the stone temples in Java which, at the time, was under Dutch occupation. The principle of this method was that "...whenever necessary, the whole building was taken to pieces, and reconstructed, stone by stone, exactly as it stood originally and reinforced by modern methods, as it never was before" (Le May 1954). Maurice Glaize, who was a conservator at the Angkor Conservancy from 1937 to 1945, applied the techniques of complete restoration to some of the large 
complexes of buildings at Angkor and it is the result of this restoration that we see today. The work of investigation and presentation was gradually extended to the whole of Cambodia. These interventions on the monuments created some controversy. George Coedes writes that:

"The lovers of Romanticism have ever reproached the French archaeologists for denuding the ruins of the vegetation which obscured them, and for making them both accessible and comprehensible. Unfortunately, we were obliged to choose between clearing the ruins or having them devoured by forest" (Coedes 1963: 10).

Bernard Philippe Groslier, a French specialist and the custodian of Angkor at the time, described in his book the approach to restoration to increase the understanding of the monument as follows:

"Some of the temple at Angkor had been known for sixty years, 'excavated' after a fashion, and frequently discussed in the literature; but when at last they were properly studied they were found to be raised on large understructures, to be surrounded by walls, ancillary buildings and entrance pavilions, and to be built on top of earlier settlements none of which had hitherto been suspected. In this field only the complete reconstruction of a building allows us to understand it completely; and we know that this is also the only way to save buildings. This, therefore, is the aim which lies before us, for we have a responsibility for the preservation of the building in our care" (Groslier 1970).

Coedes's and Groslier's opinions must reflect common practice for French archaeologists at that time since anastylosis had been carried out on several Khmer monuments not only in Cambodia but also in Thai territory. The completeness of the restoration made a substantial visual impact. Foundations and walls of the monuments were strengthened and made to align. New stones were inserted to replaced the missing ones. By comparing the photographs recording the condition of monuments before and after the interventions, it is obvious that the approach involving complete restoration was carried out to a great extent.

In 1964, the first restoration work using anastylosis was begun in Thailand at the sixth century Khmer sanctuary in Pimai, a small town in the north-eastern part of the country. It was the first collaborative project between the French and the Department of Fine Arts. Groslier planned the restoration process by using the method that had been successfully applied to several stone structures in Cambodia. The French method of anastylosis was carried out in Thailand without controversy at the beginning. It was used in restoring only stone architecture and was later accepted by the authorities as the only effective way of restoring stone monuments. Even though, the method is not applicable to brick and stucco building, the idea of complete restoration was put into practice on brick ruins as well.

\section{Restoration and Nationalism Movement}

The realization of the historical and archaeological value of historic monuments was not the only reason for conservation activities. Since our culture is our identity, historical relics have been used to support 
the idea of national identity or the identity of political movements. Cultural heritage can be seen in three essential components. First, the intellectual cultural heritage, which can be identified in the achievements of science, literature, art, and the concept of humanity. Secondly, material cultural heritage which is a concrete statement of human creativity. Thirdly, the ideological tradition moulded by historical circumstances and events which spans many centuries (Herrmann 1989: 33). It is obvious that the material culture with its tangible quality will be selected as the identification of a collective society. The need for material identity is particularly strong in a nation that has just gone through a stage of identity crisis, for instance, through major war, or being colonized. National monuments or whole cities have been restored or reconstructed throughout history in order to serve this function.

Thailand has never been colonized or devastated by war. However, nationalism and patrioticism were integrated into government policy to counter-balance the encroachment of western powers as well as communism which was considered dangerous to the stability of the nation. The new 'nationalist' movement after the 1932 revolution continued after the second World War and was supported by a succession of governments. One of the leading propagandist was Luang Vichit Vadhakarn who for a time held the position of director-general of the Department of Fine Arts. The idea of promoting nationalism through national heritage was put into practice resulting in the repair and restoration of several major national monuments especially at the two former Thai capitals, Sukothai and Ayutthaya.

In 1953 , the Department of Fine Arts started a restoration project at Sukothai. The principal approach to the conservation was to protect and consolidate the ancient structures with minimum intervention. It is mentioned in the principles that new rendering was not allowed since it would falsify the original structures. Ruined stupas where the original form could not be identified must be left as they were found and only the consolidation of the foundations was allowed. However, Piboon Songkram, the Prime Minister at the time, suggested some rather obscure principles to the working committee of the Department as follows:

"1. Repair and restore [monuments] to the form and the style of the original period as much as possible.

2. The restored monuments must able to show their age. [ie. the monuments must look old and ancient even though they have been recently repaired to their original form].

3. The conclusion is that the form [must be] the same as the original but looks old in the present context, but must not be dead" (The Department of Fine Arts 1990: 35).

The principles were carried out by the Department at Sukothai, Ayutthaya and other historical sites in the country. Most of the ruined structures were consolidated and given a new coat of render which often resulted in a change of form and proportion. Stucco sculptures and reliefs which were the decorative elements of stupas and ubosot halls were repaired in a way which, according to an art expert, caused more damage to the elements than if they had been looted by treasure hunters ( $\mathrm{Na}$ Paknam 1987: 48). 
Some of the ruined structures were completely reconstructed. The vihara of Wat Mongkol Borpit in Ayutthaya stood in ruinous condition after the fall of the city. When it was burnt down by the Burmese army, the roof fell on the gigantic Buddha image, damaging the head and the right arm. The image was repaired by King Rama V but the vihara was left as it was until the major restoration in 1955. It is an irony that this restoration project was a collaboration between the Thai and the Burmese governments. There is no doubt that the restoration is a symbolic one and that the message that the two governments wanted to communicate at that time was one of reconciliation.

The restorations of the period drew very strong criticism from many people especially from the academic sector. Most of the critics commented on the loss of archaeological evidence after the restoration, as well as the loss of aesthetic and architectural values as the result of a lack of understanding of history and style, and the poor workmanship. Some also lamented the irretrievable loss of the picturesque ruins and "...the atmosphere reminiscent of eerie power." The conflict between the Department and the academic sector has been a persistent and unresolved problem which can be summarized as arising from a difference in conservation philosophy.

In Thailand, material culture has been used as an obvious device for promoting national identity. However, we must not forget that relics of the past are only one facet of the whole cultural context. Culture can also be defined as the act of developing the moral, intellectual, and aesthetic nature of man. It is also the familiarity with and the appreciation of art, science, and humanity which can lead to enlightenment and refinement of an individual's mind. The conservation of historic monuments for the sake of national identity alone can undermine its real value. The appreciation of monuments as works of art and as products of creative and intellect minds must be taken in to account as another criterion in conservation.

\section{From Restoration to Heritage Management}

International conservation activity nowadays covers much more ground than the first movement in the nineteenth century. The objective in conservation also has changed, from the concern with archaeological and artistic values to more complex social and economic issues. The current conservation trend considers historic monuments as entities in the whole cultural context. The idea of the monument as a relic of history has been used to fulfil a number of modern functions. Monuments with historical significance are considered by modern planners as "....a product, selected according to the criteria of consumer demand and managed through the intervention in the market" (Ashworth 1994: 16). This concept has transformed the past and history to a commodity that needs to be managed and utilized in order to gain the best outcome. The resources for the heritage industry are not only the surviving historical relics but also historical events, personalities, memories, mythologies, and literary association (Ashworth 1994: 16).

History and culture have been used to support the idea of national identity. However, when history becomes a commodity, this use of the past became discriminatory. Particular aspects of history 
are selected, emphasised, and manipulated to satisfy the heritage consumers. Various museums and cultural theme parks have been created with heritage consumers in mind. They are places where particular periods of the past are reinvented and interpreted according to present attitudes towards history. In such cases, the authenticity of the past depends on the consumers' judgement. Therefore, the past is in danger of being restored according to what people would like to see rather than what actually existed.

\section{Tourism and Historic Monuments}

Historic monuments and sites are only a part of tourists' experiences. Visiting a historic site includes a rather wider experience than the monument itself. Encountering the local life, food, entertainment, shopping for souvenirs together form the whole tourists' activity. The emphasis given to historic monuments by each tourist is different depending on individual motivation. Curiosity about the past is the primary urge. Historical sites and monuments are presented and interpreted in order to inform the enquiring mind as well as the need to escape from the normal day to day present. People also seek aesthetic enjoyment from relics of the past. Romantic or exotic scenery provide a backdrop for people's imagination.

Heritage as a consumer product has always been designed to fit the consumer's need. The reconstruction of Colonial Williamsburg in Virginia is the classic example of an extreme approach to the interpretation of the past; as well as in England the reconstruction of the 'authentic' interior of several country houses. This kind of interpretation always brings problems relating to authenticity and the balance between values sacrificed during the restoration and the outcome of the intervention. It is generally agreed that the display of historical sites usually means damage and sometimes destruction. The reconstruction is equated to a modern piece of 'quasi-heritage' which has been described as "...impressive may be for the public but a monumental dodo from an academic point of view" (Hewison 1987).

Important tourist destinations suffer more than the loss of archaeological or architectural value. New facilities that form the basis of the tourism industry have to be developed. At present, when competition within the tourism market is high, tourism product has to be developed to suit the consumers as much as possible. It has been suggested that the successful product of tourism is "....an interpretation of the local historical experience in so far it can be related to, and incorporated in, the historical experience of the visitor" and the success of foreign heritage tourism industry depends on "...the resale in a different guise of the consumers' own heritage in an unexpected context within the destination country" (Ashworth 1994: 24). For developing countries in the East, the heritage consumers are western tourists who expect to experience the exotic culture in a familiar, comfortable atmosphere as they would experience it in their home countries. The development of tourist facilities is not only confined to hotels, shops, or restaurants but also includes transportation systems and other additional touristic activities that can be totally alien to the indigenous people.

Tourism has been one of Thailand's major industries since the beginning of the seventies. The nature of tourism includes 
weekend trippers, domestic holiday makers, and an increasing numbers of foreign tourists. However, tourism does not provide enough funds for the conservation of the heritage since the main economic benefit goes to the accommodation, catering, transport, and retailing businesses. The wear and tear on the fabric of monuments, as well as the disruption of indigenous culture, sometimes cannot be compensated by the economic gains that come from opening up monuments to the public. Though this fact is obvious, the support of the heritage industry by the government is extensive and has become part of its policy. The Tourism Authority of Thailand has become another major fund provider for historic monuments, especially the prominent ones. Important monasteries such as Wat Po in Bangkok receive a large proportion of grant aid towards the restoration of the monastic fabric. The Authority has a major role in the National Historical Park projects. It also sponsors several cultural programmes such as annual religious festivals organized by local authorities over the country.

\section{Historical Parks}

The government policy towards national heritage can be seen in one major conservation scheme: the National Historical Park. In 1977 the scheme was first approved for monetary support in the Fourth National Economic and Social Development Plan (1977-1981). The project expanded the conservation activity from individual monuments to complexes of monuments and their surrounding sites. The scheme was first carried out at Sukothai and later was implemented on eight other major sites. The aim of the project is to specify the boundary of the historical area, restore and conserve the monuments within the area, and develop the surrounding landscape. Most of the areas designated as historical parks are either large monumental complexes such as Phanom Rung or ancient cities such as Ayutthaya and Sukothai.

During the fifteenth century Sukothai was the centre of political, commercial, and religious vitality in the kingdom. A hundred and twenty-six ancient sites, most of them monasteries, were situated within the walls of the city and in the area beyond. Its architecture illustrates the inventiveness of Thai style that derived from the Khmer as well as Singhalese architecture. The glory of Sukothai's creative genius was its sculpture which is considered by most art historians as the apex of Thai artistic creation. Thousands of Buddha images were cast from bronze. Even though few examples remain, stone inscriptions of the thirteenth century describe the city as filled with images many of which were made of gold. The ancient city of Sukothai possessed a very advanced city plan. Archaeological evidence shows an ancient road connected Sukothai with other major cities in the north of the kingdom, and show as well there was an advanced irrigation system. The city was left in ruin at the beginning of the sixteenth century after a hundred years of being a vassal state of Ayutthaya. The modern Thai population discovered the glory of Sukothai Kingdom through several stone inscriptions, the historical remains, and the artifacts of the period. It is not surprising that the ancient city was used as the symbol for the glory of the past and its restoration was among the first schemes that the Thai government carried out.

It is mentioned in the master plan that 
the Sukothai Historical Park project is aimed "...not only at restoring the ancient structures but also calls for the development of the city as it was at the height of Sukothai civilization" (The Department of Fine Arts 1982: 7). The plan includes the landscape development which is intended to create "...an atmosphere that closely resembles the one described in the stone inscription" (The Department of Fine Art 1982: 51), as well as the relocation of about two hundreds families living in the walled city, and a major tourist development programme which means many new facilities are to be introduced to accommodate the growing number of tourists. Tourism is an important criterion in laying out the master plan of the Historical Park. The economic development of the area is the sole result of the tourist industry. One of the objectives is to increase the earnings of the population living in the vicinity by promoting various activities, particularly for the purpose of tourism. The master plan also mentions the revival of ancient festivals and ceremonies that were practised in the ancient kingdom. The Department of Fine Arts and the Tourist Authority of Thailand have coorganized these activities annually, and consequently the number of visitors during the festival period has greatly increased.

The government policy of creating a new kind of tourist attraction is emphasised in the master plan which states that the '...improvements and developments will enhance the city's atmosphere and attract more tourists' and that the restoration of Sukothai can help alter the image of Thailand as 'the land of pleasures with worldly enjoyment' to 'a land of ancient civilization' (the Department of Fine Arts 1982: 42).
When history and past relics are treated as commodities, we are faced with the danger of cultural deterioration. Culture and civilization are the creation of profound upheavals of spirit, the succession of man's creativity. Art and architecture are the physical outcome of this process. When history becomes a commodity, it forces people to relate to their own history in a different way. Instead of living in the present which is the continuity of the past that will evolve into the future, people are detached and become like spectators of their own culture. Modern attitudes towards the past have changed. People take the recreated past as a refuge from the real present. It provides the ground for nostalgic experiences. It has been suggested that:

"A past seen as open to manipulate not only undermines supposed historical varieties but implied a fragile present and portends a shaky future" (Lowenthal 1990).

The created distance between the present and the past makes the past seem 'dead' and signifies that the past can only survive when it is reconstructed and conserved.

\section{Conclusion}

The conservation of historic monuments in Thailand has developed and changed through time. Nowadays, conservation activity encompasses a wider definition and involves not only archaeological aspects but also social and economic factors. Amid the rapid change of Thai society, people often look back to their heritage and realize how important it is as a basis for their identity. Safeguarding national heritage, therefore, has become a duty of modern man and a part of government policy. In 1986, the National Cultural Policy was 
established by the Office of the Prime Minister. One of its objective is:

"...to promote the preservation of Thai culture in all aspects by encouraging research on Thai culture, restoring and developing Thai culture in order to be used as an important tool in dealing with problems in the everyday course of living,...such as problems in social, economic, and political development as well as national defence" (Department of Fine Arts 1992: 33).

From this policy, it seems that the government considers culture as an entity that can be selected and produced in order to serve various needs. Cultural heritage can be created to serve specific contemporary purposes.

It must be emphasised that the realization of the value of Buddhist heritage should not be the result of these needs alone. Buddhist monastic architecture, even in ruin, is a creation of the mind's pure intention that is directed towards the devotion to the Lord Buddha. The care of Buddhist monasteries in the past illustrated the combination of this devotion and architectural creativity. The safeguarding of Buddhist heritage, therefore, should stem from the consciousness of being a Buddhist, a comprehension of the meaning of the architecture and an appreciation of its value, as well as a recognition of the duty of a Buddhist towards architecture that is regarded as a representation of the belief. The devotion and the realization of these values, together with the modern knowledge and appropriate technology could be the foundation for the future of the Buddhist heritage. It can be conserved as well as developed, or re-created, and thus maintain its position at the core of Thai culture.

\section{References}

Ashworth, G.J. \& Lartham, P.J. 1994. Building a New Heritage: Tourism Culture and Identity in the New Europe. London: Routledge.

Fergusson, James. 1899. History of Indian and Eastern Architecture. London: John Murry.

Groslier, Bernard. 1970. Indochina. Trans. by James Hogarth. London: Frederick Muller Ltd.

Herrmann. 1990. World Archaeology - The World's Cultural Heritage. In Archaeological Heritage Management in the Modern World. Ed. by H.F. Cleere. London: Unwin Hyman.

Hewison, Robert. 1987. The Heritage Industry: Britain in the Climate of Decline. London: A Methuen Paperback.

Le May, Reginald. 1954. The Culture of South-East Asia. London: George Allen \& Unwin Ltd.

Lowenthal, David. 1990. The Past Is a Foreign Country. Cambridge: Cambridge University Press.

Spiro, E. Melford. 1972. Buddhism and Society: A Great Tradition and Its Burmese Vicissitudes. New York: Harper \& Row.

Suksamran, Somboon. 1982. Buddhism and Politics in Thailand. Singapore: Institute of Southeast Asian Studies. 1977. Political Buddhism in Southeast Asia: the Role of the Sangha in the Modernization of Thailand. Ed. by Trevor O. Ling. London: C. Hurst \& Company.

Tambiah, S.J. 1975. Buddhism and Spirit Cults in North-East Thailand. Cambridge: Cambridge University Press.

\section{Translated Pali and Sanskrit Texts}

The Dhammapada. 1959. Trans. by Narada Thera. London: John Murry.

Vinaya-Pikata (The Book of Discipline) Vol. IV (Mahavagga) and Vol. V (Chullavagga). 1962 \& 1952. Trans. by I.B. Horner. London: Lizac \& Co.Ltd. 


\section{References in Thai}

The Department of Fine Arts, Bangkok. 1982. Jodmaihet Karn Burana Wat Phrasrirattanasasadaram (The Account of the Restoration of the Royal Temple). . 1990. Jodmaihet Karn Anurak

Maung Boran Sri Satchanalai (The Account of the Conservation of Ancient Sri Satchanalai) Bangkok: Amarin Printing.

Pramoj, Kukrit. 1982. Sangkom Thai (Thai Society) in Laksana Thai. Ed. by Kukrit Pramoj. Bangkok: Thai Wattana Panich Press.

Wat Phra Chetupon Wimon Mongalaram. 1993. Prawat Wat Phra Chetupon Wimon Mongalaram (History of Wat Phra Chetupon). Bangkok:

Mahachulalongkorn Press. 